\title{
単結晶ダイヤモンドドリルを用いた 単結晶シリコンの高品位穴加工*
}

\author{
横 溝 精 一** 窪 田 真一郎 ${ }^{* *}$ 宇 野 義 幸 ${ }^{* * *}$
}

High Performance Drilling of Monocrystalline Silicon Using Monocrystalline Diamond Drill

\author{
Seiichi YOKOMIZO, Shinichirou KUBOTA and Yoshiyuki UNO
}

\begin{abstract}
Monocrystalline silicon is the most important material for semiconductor industry, and is also widely used as a component material of the semiconductor manufacturing equipment which needs the precision machining. However the high performance machining technology without micro cracks for brittle materials has not yet been established. Especially the high aspect ratio drilling less than $1 \mathrm{~mm}$ in diameter is very difficult. Therefore, the new drilling method of monocrystalline silicon was introduced in this paper. The experimental analysis made it clear that the mirror finished surface without micro cracks was obtained by using the monocrystalline diamond drill, while many micro cracks were generated in the case of sintered diamond drill. Furthermore, the removal rate and the tool life were enough for high performance drilling.
\end{abstract}

Key words: monocrystalline silicon, monocrystalline diamond drill, drilling, micro crack, reactive ion etching, brittle material

\section{1. 緒言}

単結晶シリコンは半導体産業の基艋材料として，欠かすこ とのできない材料であり,これから作られる各種デバイスの 生産量は非常に大きな成長を遂げている。これはまたデバイ ス材料として使われる一方で，その製造工程で不純物混入を 避ける必要から, 半導体製造装置の部品としても多く使われ ている，その代表例がプラズマエッチング装置の電極である. この電極には厚さ約 $5 \mathrm{~mm}$ の単結晶シリコンの円板に, エッチ ヤントガスを通すために直径 $0.5 \mathrm{~mm}$ 程度の微細穴が多数必要 であり, しかもアスペクト比が高いので，一般にはダイヤモ ンドドリルによる穴加工が行われる。しかし硬脆材料である 単結晶シリコンは加工部においてマイクロクラックが生じ易 く。これは欠陥となって使用中にウェ八上に破片が落下して 製品の歩留まりを悪化させるために，硬脆材料の高品位穴加 工技術の確立が重要な課題となっている。このため, 硬脆材 料への微細穴加工について工具の改良 ${ }^{1) \sim 33}$, 放電加工 ${ }^{4)}$, レーザ 加工 ${ }^{5)}$, 振動加工 (9 8) などの加工法の検討が行われている. し かしながら, 高品位, 高能率, 経済性などの多面的な観点か ら更なる検討が望まれている現状にある。

現在, 単結晶シリコンの穴加工用の工具としては一般的に 電着・焼結・コーティングによるダイヤモンドドリルが使用 されている.しかし，切りくずを生成する個々のダイヤモン ド砥粒に着目すると大きな負のすくい角を持つため，良好な 切削作用は期待できずマイクロクラックが生じない穴加工は 困難であると考元られる。それに対し，単結晶ダイヤモンド をドリルに用い，更に集束イオンビーム (Focused Ion Beam: 以 下，FIB と略す)装置などで切れ刃を成形すれば，鋭利な切れ 刃と同時にすくい角の改善が可能であり, 高品位穴加工が可 能となると思われる。そそこで硬脆材料である単結晶シリコン の微細穴加工の高品位化を目的とした単結晶ダイヤモンドド

* 原稿受付 平成 17 年 6 月 24 日

*正会員 岡山県工業技術センター (岡山市芳賀 5301)

.*. 正会員 岡山大学大学院自然科学研究科 (岡山市津島中 3-1-1)
リルを試作し，その加工性能について検討した.

\section{2. 加工欠陥の検出}

\section{1 マイクロクラックの検出方法}

硬脆材料の穴加工の高品位化ならびに品質管理を行ってい くには, 加工で生じたマイクロクラックを的確に検出し, 加 工技術にフィードバックしていく必要がある。従来, マイク ロクラックの検出には腐食液を用いたウエットエッチングが 行われていた. しかし, エッチング作用が等方的であるため, 微小なクラック部は明瞭には観察できない. また, 目的以外 の部分も同時に腐食されるため, 製品の機能を低下させる可 能性がある。そこで，筆者らはウェットプロセスよりもエッ チング条件の制御が容易で，異方性エッチング特性によって マイクロクラックを明瞭に検出できる反応性イオンエッチン グを利用する検出法を提案した 》. 本検出法で用いる反応性イ オンエッチング (Reactive Ion Etching, 以下 RIE と略す) 装置は, チャンバーに導入したガスに高周波電力（周波数 $13.56 \mathrm{MHz}$ 一般的）を印加してプラズマ状態とし，そこで生じたプラスイ オンを加速して対象物に衝突させる物理的作用と反応性ガス による化学的作用を利用する物理的・化学的エッチングであ り, 条件の選定によってそれぞれの特性を強調した処理が可 能である.すなわち RIEではガスの圧力を数 Pa 以下にすると イオンの運動方向が揃うため, 対象物を垂直方向に除去でき る異方性エッチングが可能となる。この性質は半導体の微細 加工にも利用され，デバイスの製造過程では不可欠な方法と なっている，腐食液によるウェットプロセスが等方性エッチ ングであるのに対して，RIE の異方性エッチングは微小なクラ ックでも明膫に顕在化させることができる，

\section{2 マイクロクラックの検出例}

単結晶シリコンへの穴加工の評価のため, 次のようにして 観察面を作製し RIEによるクラックの検出を行う。まず直径 $0.5 \mathrm{~mm}$ の焼結ダイヤモンドドリルで穴加工を行った単結晶シリ コンを切断砥石によって分割後, 粒径 $6 \mu \mathrm{m}, 1 \mu \mathrm{m}$ ダイヤモンド 砥粒による研磨によって鏡面にした。 


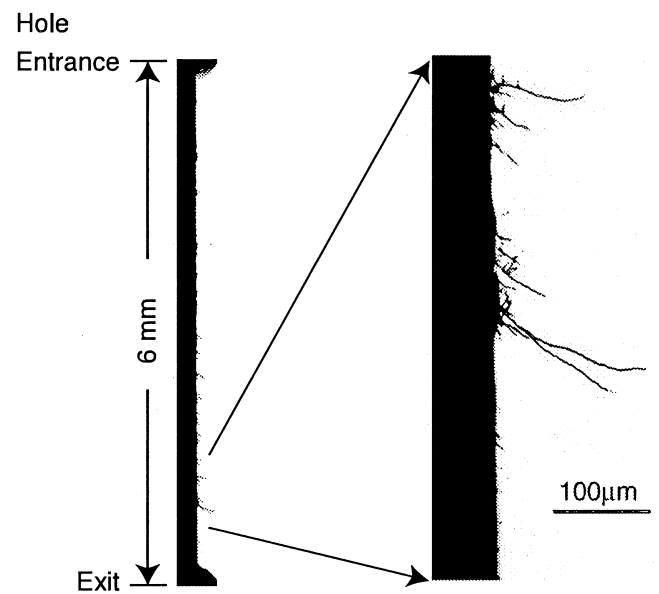

Fig. 1 Longitudinal section of the hole using sintered diamond drill

Table 1 RIE conditions

\begin{tabular}{l|l}
\hline RF power & $200 \mathrm{w}$ \\
Pressure & $13.3 \mathrm{~Pa}$ \\
Gas & $\mathrm{CF}_{4}$ \\
Gas flow rate & $20 \mathrm{sccm}$ \\
Etching time & $10 \mathrm{~min}$. \\
\hline
\end{tabular}

Fig. 2 Sintered diamond drill

図 1 は穴の縦断面を研磨後，RIE装置により。表 1 の条件 でエッチングを行った場合の穴近傍の光学顕微鏡写真である. 図から明らかなように，穴近傍に多数のマイクロクラックが 検出される。検出されたクラックはドリルの進行方向に対し て斜め前に向かって進展している.さらに穴加工の初期，す なわち穴の入口付近ではクラックの発生はほとんど見られな いが，出口に近づくにつれて発生が顕著となっていることも 分かる。 また，次の穴についても図 1 と同様に，クラックは 入口では発生せず, 出口で多数発生している。このことから, 単結晶シリコンのダイヤモンドドリルによる穴加工において も，切りくずの処理が穴の品位に大きく影響していることが 分かる.

\section{3. 焼結ダイヤモンドドリルによる微細穴加工}

\section{1 焼結ダイヤモンドドリル}

単結晶シリコンへの穴加工は一般に焼結ダイヤモンドドリ ルを用いて行われているが，多くの問題点がある. ドリルの 問題点としては, ドリル溝部へ切りくずが固着し, 切りくず の排出ができなくなったり, 先端部のコーナで生じる大きな 摩耗があげられる。これらが加工面のマイクロクラックや穴 出口部に発生する欠けとして穴の加工品質に悪影響を与えて いる．そのため CVD ダイヤモンドドリル，ドリル形状の改良， 加工条件の改善等について研究がなされている2)3.

本実験で使用した焼結ダイヤモンドドリルを図 2 に，その 先端部の SEM 写真を図 3 に示す．図 3(b) は先端部の拡大図で あり，粒径が約 $3 \mu \mathrm{m}$ のダイヤモンドで形成されていることが 分かる. 個々のダイヤモンドは結晶に由来する切れ刃が数多 く観察される．図3(a) は先端部全体を観察するため倍率を下

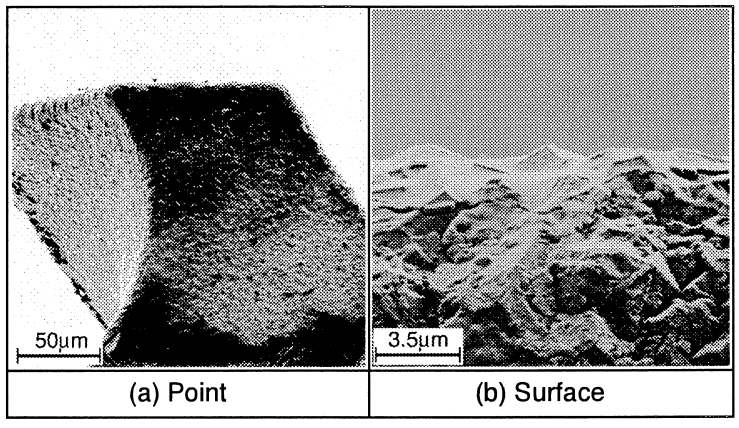

Fig. 3 SEM photographs of sintered diamond drill

Table 2 Drilling conditions for sintered diamond drill

\begin{tabular}{lr|l}
\hline Tool & & Sintered diamond drill \\
\hline Drill diameter & $D$ & $0.5 \mathrm{~mm}$ \\
Point angle & $\alpha$ & $135^{\circ}$ \\
Helix angle & $\beta$ & $35^{\circ}$ \\
\hline Revolution & $N$ & $15000 \mathrm{~min}^{-1}$ \\
Feed per revolution & $f$ & $0.5 \mu \mathrm{m} / \mathrm{rev}$. \\
Depth of step feed & $0.15 \mathrm{~mm}$ \\
Coolant & solution type \\
\hline
\end{tabular}

げた写真である。これから分かるように表面はダイヤモンド 層で覆われ，耐摩耗性は向上しているものと推測できる。し かしながらマク口的切れ刃形状を形成する稜線は非常に鈍く， 大きな切削抵抗が発生するものと思われる。 また, 表面の微 小な山凸は切りくずの排出を困難にさせるものと考元られる. 表 2 の加工条件で単結晶シリコンに 1 ステップ量ずつ切り込 みを与える方法で穴加工を行った. ステップ量は $0.15 \mathrm{~mm}$ とし， ステップ毎にドリル先端部が加工物表面から $1 \mathrm{~mm}$ 程度離れる まで上昇させて切りくずの排出を図った.

\section{2 加工穴の評価}

穴加工を行った単結晶シリコンを切断砥石で分割後, 粒径 6 $\mu \mathrm{m}, 1 \mu \mathrm{m}$ のダイヤモンド砥粒を用いて研磨仕上げをした試料 に対し，RIE装置を用いて表 3 の条件でエッチングを行った. ここで行った条件は表 1 より RF 出力を高く, 処理時間も長く しているのでエッチング量は増大し, 確実にクラックが検出 できるように設定されている．また，ガス圧力は $6.7 \mathrm{~Pa}$ と低く することにより，エッチングによってクラックの形状が大き く変化せず，元のクラック形状を保って検出するできる異方 性エッチングの性質が顕著な条件とした ${ }^{10)}$.

RIE 装置を用いてエッチングした穴緥断面の写真を図 4 に 示す. 図 4(a) から分かるように穴入り口から $1.3 \mathrm{~mm}$ 程度は光 沢のある加工面となり,クラックも観察されていない.しかし， これより穴出口に向かっては $0.15 \mathrm{~mm}$ の間隔で周期的に荒れ た加工面となり縞模様を呈した，その縞を拡大したものを図 4(b) に示す.この写真から明らかなように縞状の荒れた加工 面の下には大きなマイクロクラックがドリル進行方向に対し，

Table 3 RIE conditions for drilled hole

\begin{tabular}{l|l}
\hline RF power & $250 \mathrm{w}$ \\
Pressure & $6.7 \mathrm{~Pa}$ \\
Gas & $\mathrm{CF}_{4}$ \\
Gas flow rate & $20 \mathrm{sccm}$ \\
Etching time & $20 \mathrm{~min}$. \\
\hline
\end{tabular}




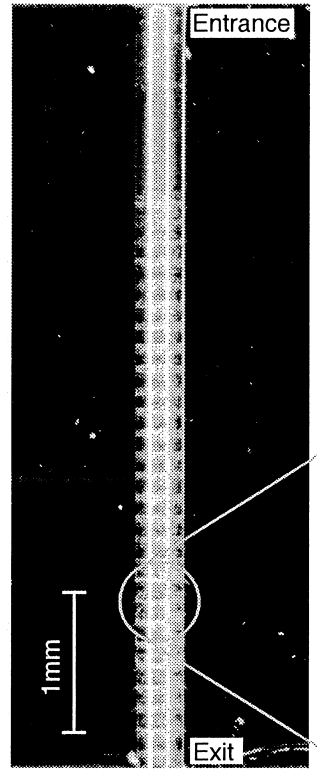

(a)

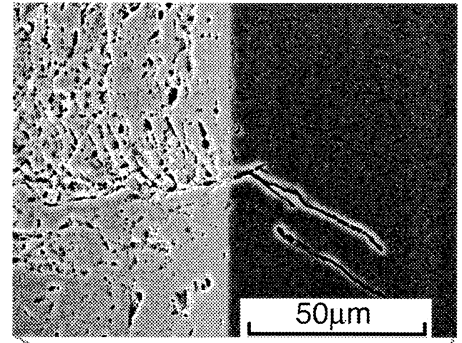

(c)

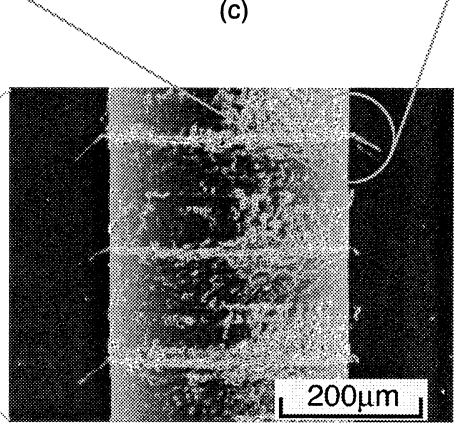

(b)

Fig. 4 Longitudinal section of the hole by sintered diamond drill

斜め前方に発生しているのが 分かる。また図4(c) の写真か らも分かるように縞状の加工 面の荒れはマイクロクラック の起点となっている. この傾 向は穴出口に向かって顕著と なっており，この様子は基本 的に図 1 と同様である. また, この周期的な縞はステップ量 と一致しており，ドリルがス テップバックする際, ダイヤ モンド切れ刃が切りくずを巻 き込むために発生していると

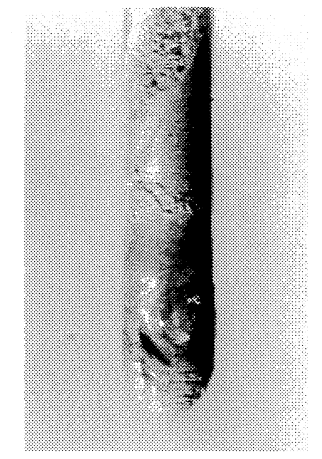

Fig. 5 Sintered diamond drill filled up by chips
考えられる。このため焼結ダイヤモンドドリルを用いた単結 晶シリコンの穴加工においても, 切りくず処理が重要な要件 である．焼結ダイヤモンドドリルで穴加工を行っていくとド リル溝部に切りくずが固着し，ステップバックを行っても完 全な切りくず除去が行えず，極端な場合には図 5 に示すよう に溝部が切りくずによって完全に埋まった状態となる。この ため切りくずが固着しない溝部の表面処理あるいは切りくず が凝集しない切削油剤の開発が望まれる.

\section{4. 単結晶ダイヤモンドドリルによる微細穴加工}

\section{1 単結晶ダイヤモンドドリルの試作}

高品位微細穴加工の要請に対し，マイクロクラックの発生 は大きな問題であり，その問題の解決には鋭利な切れ刃で良 好な切削状態を実現する必要があると考えられる。そこで単 結晶ダイヤモンドに研磨加工を施すことにより，鋭利な切れ 刃を持つドリル先端部を作製した，その仕様を表 4 に，模式 図を図 6 に示す。対稜角 $90^{\circ}$,(111) 面で構成される先端部が あり，焼結ダイヤモンドドリルのように鈍い切れ刃ではなく， 鋭い切れ刃とした.この鋭利な稜線は良好な切削作用を発揮 するもの思われる。また，その下部に正方形の断面を持つス
Table 4 Specification of monocrystalline diamond drill

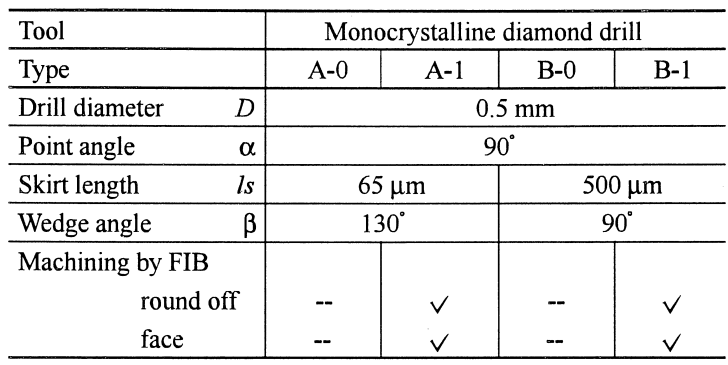

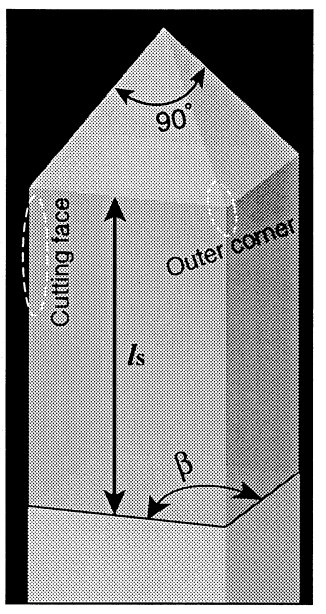

Fig. 6 Schema of machined monocrystalline diamond drill

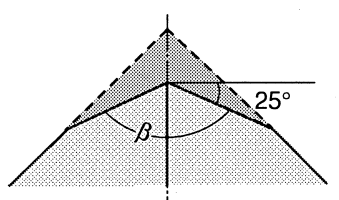

Fig. 7 Shaping of the cutting edge of skirt part in type A drill (top view)

カート長さ $l s$ の角柱状部分 を形成し，この部分にはリー マ工具のように壁面を切削仕 上げする機能を発揮すること を期待した。 スカート長さ $l s$ は夕イプAでは $65 \mu \mathrm{m}$ と短く,
タイプ B では 500um と長くし，穴壁面の仕上がりへの影響を 調査することにした。このダイヤモンド先端部は超硬合金 の シャンクにろう付され，対角線長さ $0.5 \mathrm{~mm}$ の単結晶ダイヤモ ンドドリルを作製した。

タイプ A はスカート長さ $l s$ を $65 \mu \mathrm{m}$ と短くしているため, 工具寿命が短いことが考えられる。 またスカート部の刃物角 $\beta$ は $90^{\circ}$ であり，点対称であるのですくい角は $-45^{\circ}$ と見なす ことができる。このスカート部を図 7 のように研磨し刃物角 $\beta$ を $130^{\circ}$ に加工した。この場合スカート部は大きな負のすくい 角となるが，長寿命になることが考えられる，なお，夕イプ B のスカート部の刃物角 $\beta$ については $90^{\circ}$ のままとした.

焼結ダイヤモンドドリルの場合, 穴加工を行っていくとド リルの外周コーナは丸く摩耗してくる。この外周コーナには ドリル前方と穴壁面の双方から大きな力が作用している。そ して，これはまた加工反力として同時に被削材に対しても作 用する。これらはドリルの外周コーナの摩耗, 壁面のマイク ロクラックや穴出口の欠けの原因となっている。これらの改 善のため, あらかじめその外周コーナに丸みをつけたドリル では，これらが減少することが経験上知られている。これら の観点から切れ刃となる先端部とスカート部の稜線が交わる 角部を FIB 装置により丸めることにした。図 8 は FIB で除去 加工した外周コーナの丸め成形状態の SEM 写真である。写真 からも明らかなような図 8(a)の FIB 加工前の外周コーナは非 常に鋭い稜線で形成されている。この稜線が交わる外周コー ナを FIB で丸めたものが図 8(b) である。その除去形状は図に 示すように外周コーナから所定の長さ離れた点を結ぶ線に垂 


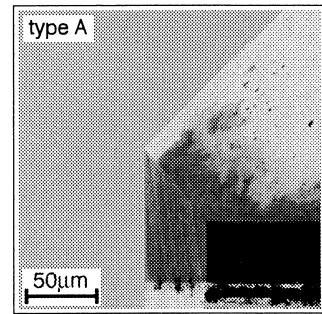

(a) before machining

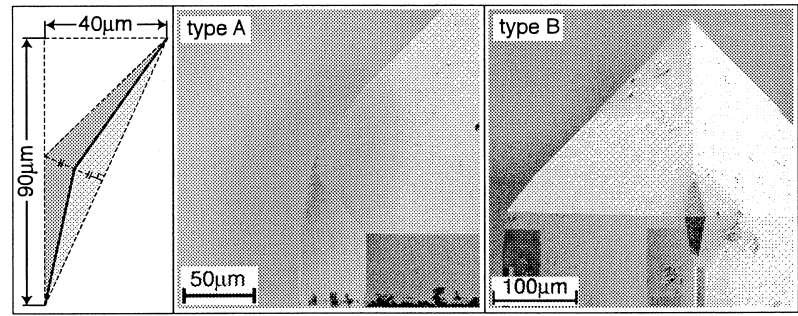

(b) after machining by FIB

Fig. 8 Shaping for rounding off outer corner

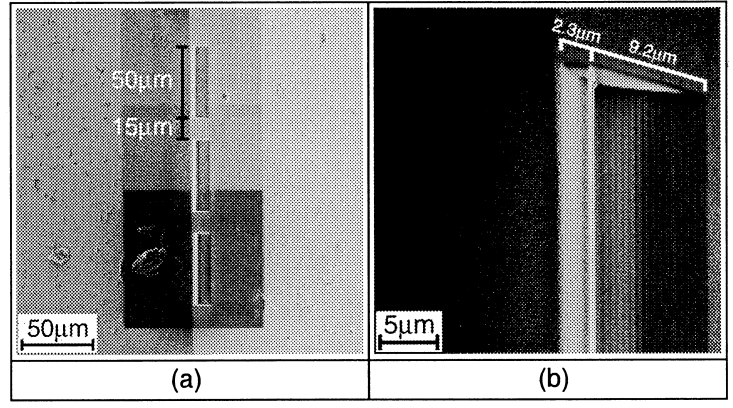

Fig. 9 Machining of cutting face to the skirt part

線を下ろし，その 2 等分した量を除去して丸みを付けた. 図 8(b) のタイプ B はその丸み部分を正面から見たものである.

スカート部における切れ刃のすくい角はタイプ A では $-65^{\circ}$, タイプ Bでは $-45^{\circ}$ の負の值となっている. そこですくい面に FIB を用いて凹部を形成することにより，すくい角をできるだ け小さくすることを試みた. 図 9 はFIBで加工したスカート 部の SEM 写真である. 図 9(a) から分かるように長さ $50 \mu \mathrm{m}$ の 凹部が $15 \mu \mathrm{m}$ の間を開けて形成されている. 図 9(b) はその凹 部の拡大写真である. 凹部は二段階で成形されており, スカ 一ト部の平面を基準にして, 最初幅 $2.3 \mu \mathrm{m}$, 長さ $50 \mu \mathrm{m}$ で最も 深い箇所が $1.7 \mu \mathrm{m}$ となるような斜面を形成し, 続いて幅 $9.2 \mu \mathrm{m}$, 長さ $50 \mu \mathrm{m}$ で最も深い箇所が $2.7 \mu \mathrm{m}$ の斜面を形成した.

このようにして, 表 4 に示すような 4 種類の仕様の単結晶 ダイヤモンドドリルを作製した。

\section{2 単結晶ダイヤモンドドリルによる加工穴}

被削材には厚さ $5 \mathrm{~mm}$ の単結晶シリコンを用いて, 結晶方位 (100)の面に対して垂直方向に穴加工を行った。 なお，穴出口 側にはバックアップのための板材は使用せず, 表 5 の加工条 件で穴加工を行った。 また, 加工された穴は 3.2 節で行った方 法と同様に切断砥石で切断後, 研磨し, 表 3 の条件 (微細な又 イクロクラックも検出できる条件 ) で RIE 装置によるエッチ ングを行った

タイプ A のドリルを用いて加工を行った穴の縦断面を図 10
に示す．焼結ダイヤモンドドリルの場合には，穴出口に近づ くにつれて加工面下には大きなクラックが発生していたが, 単結晶ダイヤモンドドリルの場合は FIB による加工の有無に 関わらず大きなクラックは全く発生していないことが分かる. しかし, A-0, A-1 の両者とも左側に示す全断面にわたって光沢 は見られない. クラックの発生しやすい穴出口付近を拡大し た右側の SEM 写真を見ると, 光沢がないのは加工面に生じた 波状の凹凸によるものであることが分かる. A タイプの場合, スカート長さは $65 \mu \mathrm{m}$ と短いことに加え, 先端の切れ刃だけ が穴壁面に接しているため, $10000 \mathrm{~min}^{-1}$ と高速で回転させる とびびり振動が発生し, 波状の加工面になったと考えられる. クラックについて観察すると, FIB 加工を行っていない A-0 は, 壁面に多くのチッピング状クラックが存在することが分かる. FIB 加工を行った A-1 では一部平滑な部分も観察され, クラッ クも減少していることから, 若干のすくい角の効果が認めら れた. しかし，すくい角の改善を行っても完全に平滑な壁面 を得るには至らず, びびりの問題も改善されていない. 加え て大きな課題は加工能率の低さにあった. 表 5 の送り量 0.04 $\mu \mathrm{m} / \mathrm{rev}$. は加工結果から見てこれ以上に大きくすることができ ず, ステップ量も $0.005 \mathrm{~mm}$ より増大させることができなかっ た值であり，A タイプのものは実用域の加工能率に到達する のは困難であると思われる。これはスカート部の刃物角を $130^{\circ}$ にしたことで, 切りくずの排出が困難になったことが原因し ているのではないかと考えられる.

図 11 は B タイプのドリルを用いて加工した穴の縦断面を 示す。この場合には $\mathrm{A}$ タイプで見られた欠点は全く観察され ない. すなわち B-0, B-1 ともに穴入り口から出口まで全域に

Table 5 Drilling conditions for monocrystalline diamond drill

\begin{tabular}{l|c|c|c|c}
\hline Type & A-0 & A-1 & B-0 & B-1 \\
\hline Revolution & N & \multicolumn{4}{|c}{$10000 \mathrm{~min}^{-1}$} \\
\hline Feed per revolution f & $0.04 \mu \mathrm{m} / \mathrm{rev}$ & $1 \mu \mathrm{m} / \mathrm{rev}$. \\
\hline Depth of step feed & \multicolumn{2}{|c}{$0.005 \mathrm{~mm}$} & $0.05 \mathrm{~mm}$ \\
\hline Coolant & \multicolumn{3}{|c}{ solution type } \\
\hline
\end{tabular}

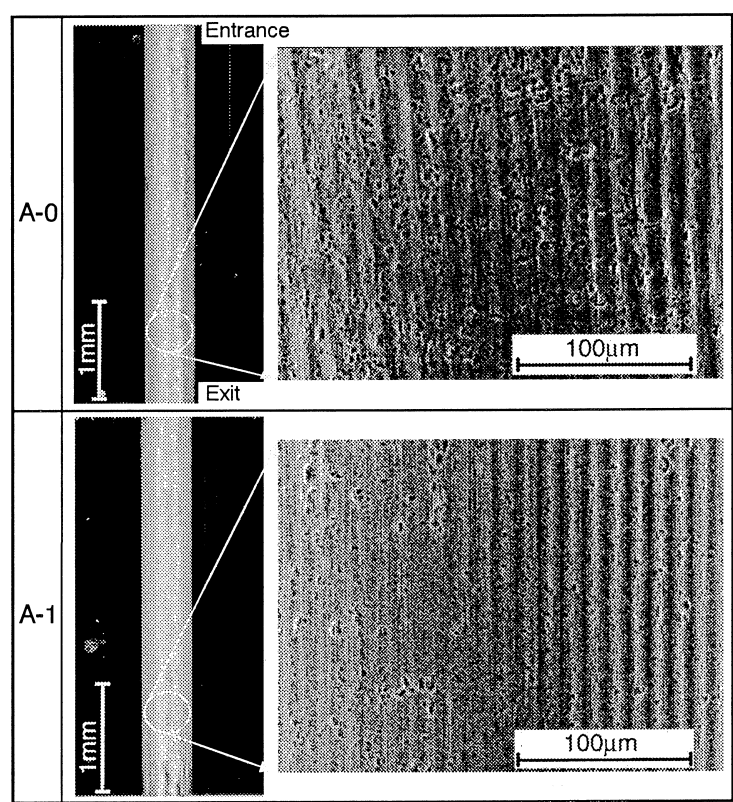

Fig. 10 Longitudinal section of the hole with type A drill 


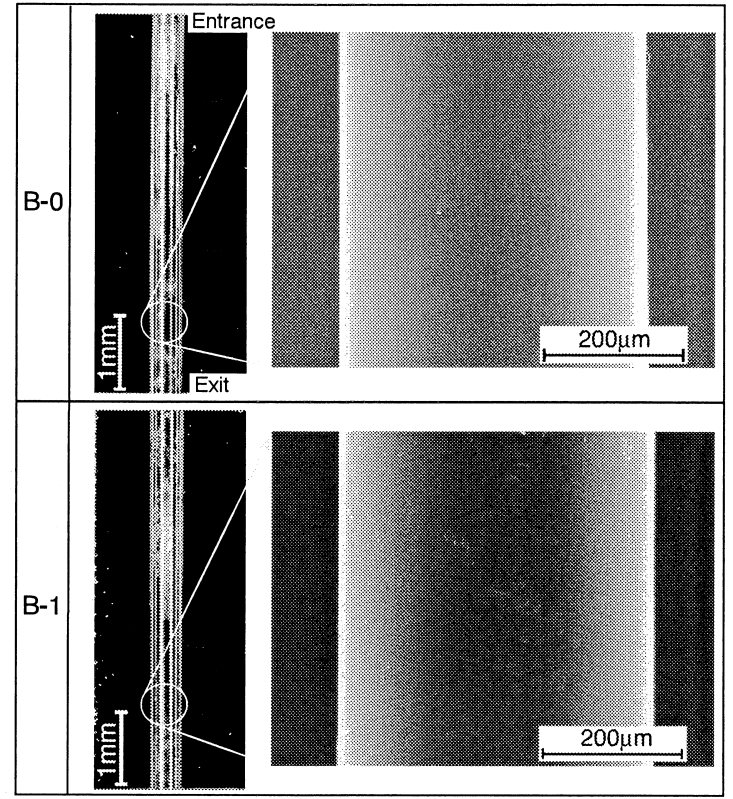

Fig. 11 Longitudinal section of the hole with type B drill

わたって良好な切削作用によると考えられる光沢面が得られ， 右側の拡大した SEM 写真からも分かるように, 微細なマイク ロクラックが検出できるエッチング条件においても, 加工面 にクラックは全く認められない. エッチングされた表面は研 磨後の表面と同等であり, 無欠陥の単結晶シリコンをエッチ ングしたのと同じ状態であった.このように高品位の加工面 が得られたのはスカート長さが $500 \mu \mathrm{m}$ と A タイプの 7.7 倍の 長さがあり,びびり振動が抑えられたこととドリルの外周コ 一ナ付近では生じていた切り残しが，スカート下部に向かっ て漸次少なくなり, 微小切り込みによる延性モード切削とな つたためと考えられる.さらにB夕イプのスカート断面は正 方形であるため, A タイプより切りくずの排出において有利 であったことが高品位加工に繋がったと思われる. 以上の結 果から考察すると, FIB による付加加工よりスカート長さを 長くすることの方が支配的であり, B タイプのドリルを用い ることで高品位微細穴加工が実現することが判明した。この 場合の送り量は $1 \mu \mathrm{m} / \mathrm{rev}$. ですでに実用域にあるが，ステップ 量 $0.05 \mathrm{~mm}$ をさらに増大させることにより経済性も満足した高 品位微細穴加工が実現するものと思われる. B 夕イプでの穴 加工における出口の光学顕微鏡写真を示したのが図 12 であ る. バックアップのための板材を用いていないにもかかわら ず大きな欠けは発生していない。特に FIB 加工を施さなかっ た B-0 では 1 番目と 300 番目の穴の出口品質は全く同等であ り，この場合にはダイヤモンドの寿命も問題ないように思わ れる。一方, FIB 加工を行った B-1 では焼結ダイヤモンドドリ ルの経験からの予想に反し, 300 番目の加工穴は若干形状精度 が低下している。これは FIB 加工後のダイヤモンド切れ刃が 寿命の観点からは問題があったためと思われる.

以上の実験結果より, B-0 タイプのように成形した単結晶夕゙ イヤモンドドリルを用いれば, 工具寿命, 加工能率の点でも 実用的な単結晶シリコンへの高品位微細穴加工が可能となる ことが明らかとなった。

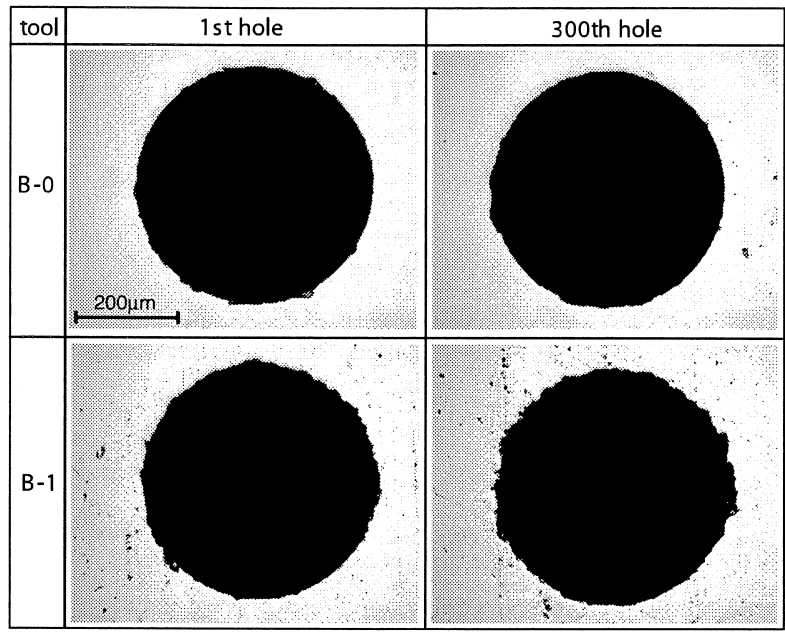

Fig. 12 Hole exit by the type B drill

\section{5. 結 論}

単結晶シリコンに対する高品位微細穴加工を目的に, 単結 晶ダイヤモンドドリルの適用性について実験的検討を行った. 本研究によって得られた主な結論は以下のようである.

(1) 焼結ダイヤモンドドリルを用いてステップ送りで穴加 工すると，ステップ量の間隔で加工面粗さが悪化したり， マイクロクラックが生じやすい.

(2) 鋭利な稜線を持つ単結晶ダイヤモンドドリルを用いる とマイクロクラックのない加工が可能である.

(3) ドリル軸方向に長く鋭い単結晶ダイヤモンドの稜線は 優れた切れ刃となり, 高品位微細穴加工用の優れた工具 となる.

\section{参 考 文 献}

1）升田雅博, 大山啓, 森義典, 半田伸一, 武知清孝, 小川仁: 小径 ダイヤモンド電着工具によるアルミナセラミックへの通し穴加工 (第 1 報), 精密工学会誌, 71, 1(2005)105.

2) 亀岡誠司, 増田敬, 早崎浩, 本西英, 内田仁 : CVD ダイヤモン ドドリルによる単結晶 Si の穴あけ加工性能, 精密工学会誌, 68, $1(2002) 142$.

3) 亀岡誠司, 増田敬, 早崎浩, 本西英, 内田仁 : CVD ダイヤモン ドドリルの単結晶 $\mathrm{Si}$ 穴あけ加工への適用, 精密工学会誌, 68, 10(2002)1362

4）宇野義幸, 䆶田真一郎, 横溝精一, 岡田章, 田中英登: 単結晶 シリコンの微細穴放電加工に関する研究, 電気加工学会誌, 30 , 65(1996)9.

5）窪田真一郎，横溝精一，宇野義幸：エキシマレーザによる単結 晶シリコンの加工特性, 1995 年度精密工学会秋季大会学術講演 会講演論文集, (1995)343.

6) 田中信一, 高木純一郎，横沢毅，長谷川徳慶，山崎健司：小径 穴超音波加工に関する研究 (第 1 報 : 種々の加工条件が加工速 さに与える影響), 砥粒加工学会誌, 48, 6(2004)324。

7) 田中信一, 高木純一郎, 横沢毅, 長谷川徳慶 : 小径穴超音波加 工に関する研究（第 2 報：工具小径化が加工速さに与える影響), 砥粒加工学会誌, 49,5(2005)245.

8) 田中信一, 高木純一郎, 横沢毅, 長谷川徳慶: 小径穴超音波加 工に関する研究（第 3 報：工具材質の違いが加工特性に与える 影響), 砥粒加工学会誌, 49,5(2005)250.

9) 横溝精一, 窪田真一郎, 宇野義幸：RIE を用いた単結晶シリコン 加工面クラックの新しい検出法, 精密工学会誌, 71, 10(2005)1291

10) Seiichi YOKOMIZO, Shinichirou KUBOTA, Yoshiyuki UNO : A Newly Developed Crack Detecting Method Using Reactive Ion Etching, Proc. of The $7^{\text {th }}$ ICPMT, (2004)664. 